\title{
Effects of gamma radiation on quantitative traits and genetic variation of three successive generations of cowpea (Vigna unguiculata (L.) Walp.)
}

\author{
Vanmathi S, Dhanarajan Arulbalachandran* \& Vasudevan Soundarya \\ Division of Crop Mutation and Molecular Breeding, Department of Botany, Periyar University, Salem 636 011, Tamil Nadu, India \\ *Email: arul78bot@gmail.com
}

\section{ARTICLE HISTORY}

Received: 17 December 2020

Accepted: 03 May 2021

Available online: 01 July 2021

\section{KEYWORDS}

Gamma irradiation

Genetic variability

Mutation

SCoT marker

Yield

\begin{abstract}
An annual pulse crop cowpea (Vigna unguiculata (L.) Walp.), commonly named southern pea, is a nourishing constituent for the human diet and fodder. Gamma rays are a potent mutagenic agent to stimulate genetic variation with better characteristics, improving the yield relating traits in crops. Hence, the present study focused on exploring genetic variation between three generations in the mutant populations of cowpea through SCOT markers. The mutant populations of three successive generations, $M_{1}, M_{2}$ and $M_{3}$, were induced by different doses [200, 400, 600, 800, 1000 and 1200 Gray (Gy)] gamma irradiation. The results depict that the quantitative characters were reduced by increasing the dosage of gamma irradiation in the $M_{1}$ generation. In contrast, the second and third generation of plants showed a significant increase in yield and yield contributing traits than control and the maximum increase was noticed at $200 \mathrm{~Gy}$ and $400 \mathrm{~Gy}$. Days to first flowering was delayed in irradiated plants than control of $M_{1}$ generation. In contrast, in consecutive generations $\left(M_{2}\right.$ and $\left.M_{3}\right)$, the early first flowering was noticed at $400 \mathrm{~Gy}$ and late flowering was observed at $800 \mathrm{~Gy}$ compared respectively to control and other doses. Seed yield per plant mean value was increased at $200 \mathrm{~Gy}$ in both generations $\left(M_{2}\right.$ and $\left.M_{3}\right)$; it may produce new genotypes to desirable traits such as yield and quality. SCOT markers were used to explore genetic variation at the genomic level of mutant populations and screened with eight primers. Among them, seven primers showed amplification of 222 bands, in which 133 bands showed polymorphism. The polymorphic bands varied from 3.03-96.07\%. The genetic variation, such as the number of different alleles $(\mathrm{Na})$, effective number of alleles $(\mathrm{Ne})$, Shannon's information index (I), expected heterozygosity $(\mathrm{He})$ and unbiased expected heterozygosity (uHe) showed an average value of $1.352 \pm 0.092,1.278 \pm 0.027,0.293 \pm 0.023,0.184 \pm 0.016$, and $0.194 \pm$ 0.016 , respectively. AMOVA depicted significant genetic variation between all generations and indicated a total of $95 \%$ within populations and $5 \%$ among population variation by the marker used. The present investigations prominently showed that the variations induced by gamma irradiation were inherited from successive generations of the improvement in cowpea quantitative traits. This investigation gives acceptable proof that the SCOT markers are a valuable tool to identify the genetic variation among the three generations of cowpea.
\end{abstract}

\section{Introduction}

Cowpea [Vigna unguiculata (L.) Walp.] is the most cultivated and consumed tropical grain legume, especially in Africa and Asian countries, which contain essential protein sources and rich in amino acids (1). The grain of cowpea contains protein (23\%) and carbohydrate $(57 \%)$ as a major component and leaves contain $27-34 \%$ of proteins (2). Cowpea production was hindered by quality, low grain yields, and lack of improved cultivars (3). On the other hand, cowpea's crop improvement through hybridisation and recombination is complicated because of the cleistogamous nature of flowers. Therefore, inducted mutation plays a vital role in creating variability for enhancing crop yield with desired traits.

The physical and chemical mutagenesis creates genetic variation, produces new varieties with enhancing characteristics (4). Mutation breeding can be a valuable technique to traditional breeding methods and have been successful in the improvement of qualitative and quantitative traits in many crops such as cowpea (5-7), soybean (8, 9), black gram (10-12). Moreover, mutation breeding takes less time, easy to handle and is highly useful in producing crop cultivars than traditional breeding methods $(13,14)$. An updated database of IAEA/MVD (International Atomic Energy 
Agency)/(Mutant Variety Database) maintained a list of 3308 varieties released through artificial mutations; 16 mutant varieties of cowpea have been registered, in which ten mutant varieties released by physical mutagen - gamma rays (15). The mentioned 16 mutant varieties have different specific agronomic characteristics in various geographical zones based on the needs they developed.

Different types of mutagenic agents, irradiations (ionising and non-ionising), have been effectively applied for the induced mutation in different crops (16). Among the physical mutagens, gamma radiation is probably the best to induce hereditary changes in crops. The physical mutagens, like ionising radiation, produced $89 \%$ of mutant varieties worldwide (17). Among these, $70 \%$ of genetic changes have been created by gamma irradiation alone (18). Many mutant varieties, such as crops resistant to biotic, abiotic factors and plants with desired traits, have been produced through gamma irradiation (19). Genetic variability is an essential trait for plant breeding, contributing to significant genetic variability through increasing DNA polymorphism (20). Genetic markers like the marker-based selection is a remarkable tool to plant breeders for selecting and evaluating specific traits (21). The gamma radiation has induced changes in the morphological and quantitative traits in cowpea and black oats $(22,23)$. The start codon targeted (SCoT) marker was developing based on the short conserved region flanking the start codon (ATG) in the plant gene (24). It correlated with functional genes with their response of corresponding traits. The SCoT marker has extended primer (18-mer) length and develop high polymorphisms than dominant and co-dominant markers $(25,26)$. The present study focused on the effect of gamma irradiation in the yield and yielded contributing traits of three successive generations of cowpea and the genetic variability analysis using SCOT marker for $M_{1}, M_{2}$ and $M_{3}$ generations of cowpea.

\section{Materials and Methods}

\section{Seed material and Mutagenic treatment}

The healthy and well-matured cowpea seeds ( $V$. unguiculata) CO-7 was procured from the National Pulse Research Centre (NPRC), Vamban, Pudukkottai, Tamil Nadu, India. A hundred seeds per set were packed for each dose in a paper cover to subject irradiation such as 200, 400, 600, 800, 1000 and 1200 Gy and non-irradiated seeds used as control. The source of gamma irradiation ${ }^{60} \mathrm{Co}$ (Cobalt) was emitted $28 \mathrm{~Gy} / \mathrm{min}$ dose rate in every seed and the facility was used in Radiological Safety Division, Indira Gandhi Centre for Atomic Research (IGCAR), Kalpakkam, Chennai, Tamil Nadu, India. In the present study, the raising of $M_{1}, M_{2}$ and $M_{3}$ generations was carried out from 2016-2019 with respective seasons in Botanical Garden, Department of Botany, Periyar University, Salem, Tamil Nadu, India.

\section{Field preparation and Experimental Design}

The organic fertiliser (Cow Dung) was impregnated in the cultivated field and laid out into three plots, which consists of 6 rows. The experiment was designed in a randomised block design (RBD) in 2016-2017 for $\mathrm{M}_{1}$ generation and the seeds cultivated along with control in three replication. The plant distance was maintained at 10-15 cm interval with spacing at $45 \mathrm{~cm}$ between the rows. Weeds controlled at regular intervals and cultivation practices such as irrigation, manures, pesticides and insecticides were done for proper growth. Among different irradiation doses, the plants were survived at 200 Gy, 400 Gy, 600 Gy and 800 Gy, along with control. However, the higher doses, such as 1000 Gy and 1200 Gy, showed the least survival rate; hence those seeds were discarded without further investigation. All the biometrical characteristics were scored in the $\mathrm{M}_{1}$ generation at the harvest stage.

The $\mathrm{M}_{1}$ seeds were collected separately based on different doses and raised $\mathrm{M}_{2}$ generation. Seeds harvested from $M_{1}$ plants were bulked for each dose and raised in the field with triplicates in RBD during 2017-2018. After reap, the $\mathrm{M}_{2}$ plants packed in individual bags based on irradiation doses and raised in the field for $\mathrm{M}_{3}$ generation with triplicates followed by RBD. After maturation, the plants were harvested, and seeds were stored separately in polythene cover with respective doses marked. The quantitative traits of $\mathrm{M}_{1}, \mathrm{M}_{2}$ and $\mathrm{M}_{3}$ generations were evaluated during 2016-2017, 2017-2018 and 2018-2019 with respective seasons (Fig. 1).

\section{DNA isolation and SCoT amplification}

The treated and control plant leaves (200 mg) of $V$. unguiculata from three successive generations were extracted for genomic DNA based on the HipurA ${ }^{\mathrm{TM}}$ SuperPlant DNA purification kit (Himedia, Code: MB571; Mumbai, India). The SCoT primer (8 sets) was custom synthesised by Sigma Aldrich (Bangalore, India), and it consists of GC content between 50-61\% (Table 1). The optimised PCR reaction was performed in PCR Thermal Cycler (Cyberlab, Smart PCR) with

Table 1. List of SCoT primers used for the study.

\begin{tabular}{ccc}
\hline S. No. & Name of primer & Primer sequence (5'-3') \\
\hline 1. & SCoT1 & CAACAATGGCTACCACCA \\
\hline 2. & SCoT2 & CAACAATGGCTACCACCG \\
\hline 3. & SCoT3 & CAACAATGGCTACCACGC \\
\hline 4. & SCoT6 & ACGACATGGCGACCAACG \\
\hline 5. & SCoT7 & ACGACATGGCGACCATCG \\
\hline 6. & SCoT8 & ACCATGGCTACCACCGAC \\
\hline 7. & SCoT09 & ACCATGGCTACCACCGAG \\
\hline 8. & SCoT10 & ACGACATGGCGACCCACA
\end{tabular}

GoTaq G2 Green PCR master mix (Promega, Cat: M7822; Madison, USA) contains $1 \mathrm{x}$ concentration of $12 \mu \mathrm{l}$ reaction mixture with the following PCR program: 3 minutes $94{ }^{\circ} \mathrm{C}, 40$ cycles of $1 \mathrm{~min}$ at $94^{\circ} \mathrm{C}, 1 \mathrm{~min}$ at 50 ${ }^{\circ} \mathrm{C}$, $2 \mathrm{~min} 72{ }^{\circ} \mathrm{C}$, followed by 5 minutes of final extension at $72^{\circ} \mathrm{C}$. The PCR reactions $(12 \mu \mathrm{l})$ were checked on $1.5 \%$ agarose (Himedia, Mumbai) in $1 \mathrm{x}$ TAE buffer gel with $50 \mathrm{~V}$ applied current. The amplified profiles were visualised under a UV Transilluminator (Medox-Bio ${ }^{\mathrm{TM}}$, UV Transilluminator Dual). 


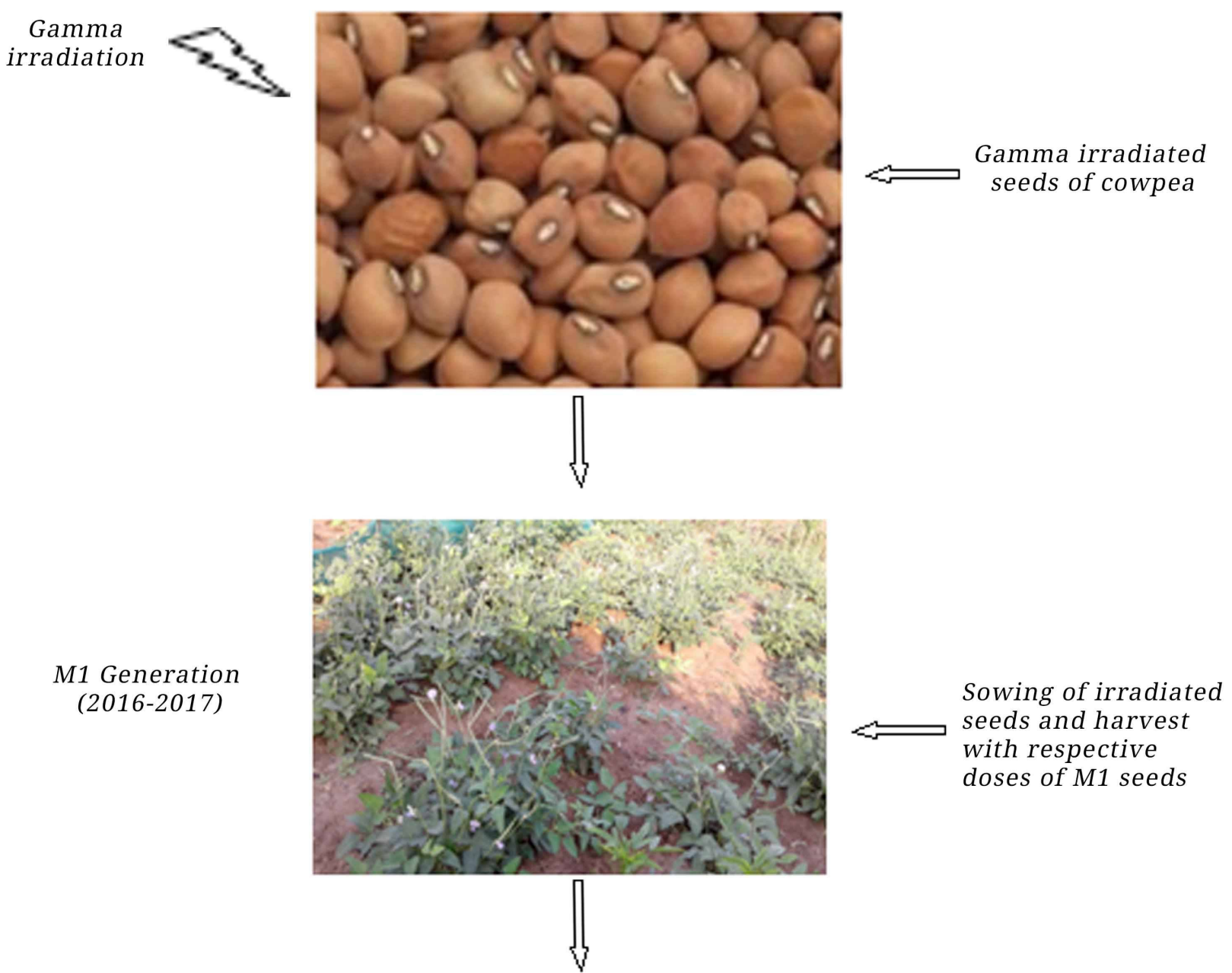

M2 Generation (2017-2018)

M3 Generation (2018-2019)
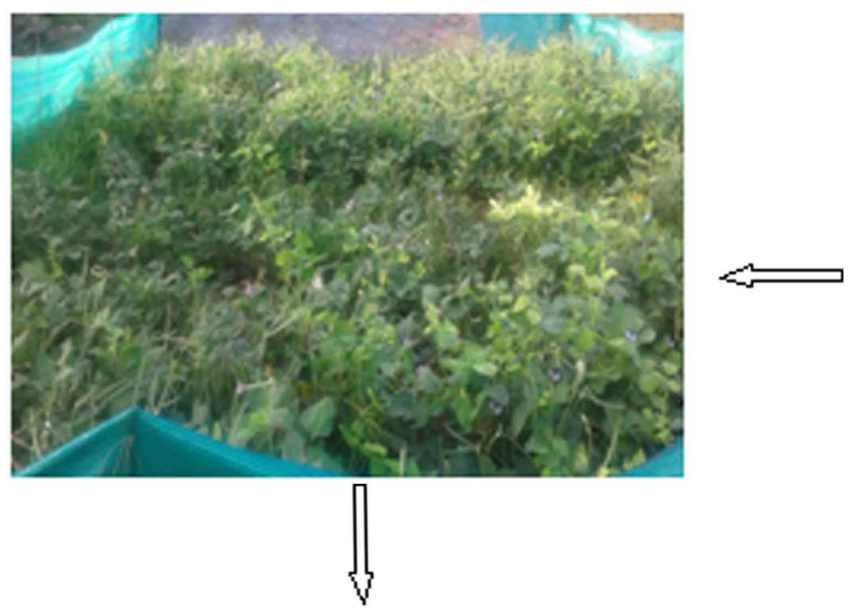

Sowing of $M 1$ seeds and harvesting individual doses of M2 seeds

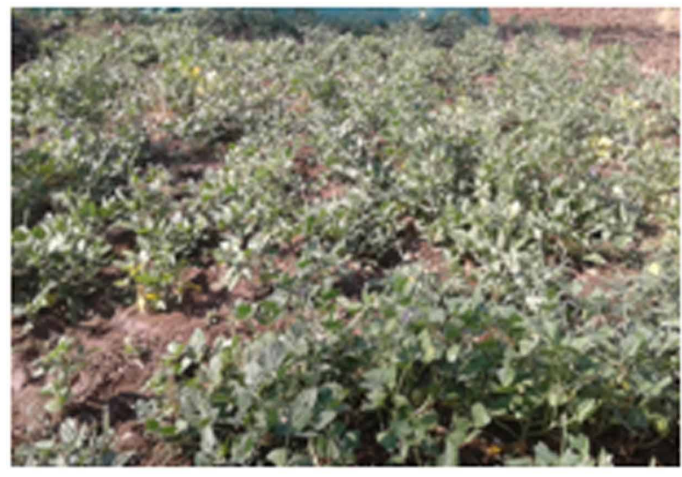

Sowing of M2 seeds and harvesting individual doses of $M 3$ seeds

Fig. 1. Field experiments: Cowpea with the effect of gamma irradiation. 


\section{Data analysis of DNA amplicons}

The unambiguous SCoT amplicons were manually converted into a binary matrix as presence (1) or absence (0) of the resulting band. The Unweighted Pair Group Method with Arithmetic Mean (UPGMA) construction method, similarity coefficient (27), and pairwise genetic similarity of Jaccard's similarity coefficient (28) were assessed in FreeTree software, ver. 9.1. The original pattern was resampled with 1000 times bootstrap, and a consent tree was developed. All tree was laid out using Tree View ver. 1.6 (29). The percentage of polymorphic variation was calculated by using the following formula:

$$
\text { Percentage of Polymorphism }=\frac{\text { Number of polymorp hic bands }}{\text { Total number of bands }} \times 100
$$

\section{Genetic diversity}

Estimation of genetic diversity like number of different alleles $\left(N_{a}\right)$, Effective alleles $\left(N_{e}\right)$, Shanon's information index (I), Expected heterozygosity $(\mathrm{He})$ and Nei's expected heterozygosity $(u H e)$, Principal Coordinate Analysis (PCoA) and Analysis of molecular variance (AMOVA) were performed in GenAlEx v.6.1 (30).

\section{Data Collection and Statistical Analysis}

Observations of various morphological and quantitative traits were recorded for $\mathrm{M}_{1}, \mathrm{M}_{2}$ and $\mathrm{M}_{3}$ generations (Table 2). One-way ANOVA and Pearson Correlation were employed to understand better trait-associated characters in $\mathrm{M}_{1}, \mathrm{M}_{2}$ and $\mathrm{M}_{3}$ generations using a statistical package (SPSS 21 for Windows).

\section{Results}

Different doses of gamma rays were induced, and the changes of various morphological and quantitative (yield) traits were recorded for $M_{1}, M_{2}$, and $M_{3}$ generations.

\section{Quantitative traits in $M_{1}$ generation}

Morphological and quantitative characters were reduced with increasing gamma irradiation doses except for days to first flowering (Table 3). The treated plants were taken more days to flower than per plant, the number of fruit cluster per plant, the number of pods per plant, the number of seeds per pod, pod length (cm), a hundred seed weight $(\mathrm{g})$ and seed yield per plant (g) were gradually reduced with increasing doses of gamma irradiation than control.

All quantitative characters were reduced at 200 Gy, and the maximum reduction was noticed at 800 Gy than control. In this study, statistical analysis showed that day to first flowering depicts a significant negative correlation $(p<0.01)$ among yield characters; hence, the yield was reduced at $\mathrm{M}_{1}$ generation (Table 6).

\section{Quantitative traits in $M_{2}$ and $M_{3}$ generations}

A significant improvement was noted in the quantitative traits such as plant height, number of leaves per plant, days to first flowering, number of fruit cluster per plant, number of pods per plant, number of seeds per pod, a hundred seed weight and seed yield per plant in $\mathrm{M}_{2}$ and $\mathrm{M}_{3}$ generations (Table 4 and 5). The present result showed that the plant was heightened at $200 \mathrm{~Gy}$ than control. The correlation coefficient confirmed that the plant height was significantly positive correlated to seed yield per plant $(p<0.01)$ (Table 7). The plant height was substantially increased at $200 \mathrm{~Gy}$ in both $\mathrm{M}_{2}$ and $\mathrm{M}_{3}$ generations compared to other doses and control. The decrease in the number of branches per plant was recorded at $600 \mathrm{~Gy}(3.9 \pm 0.16)$ in $\mathrm{M}_{2}$ and $400 \mathrm{~Gy}$ (4.2 \pm 0.26$)$ in $M_{3}$ generations. However, a significant increase was observed in the number of leaves per plant at $200 \mathrm{~Gy}(126.86 \pm 2.65)$ in $\mathrm{M}_{2}$ generation.

In contrast, the $\mathrm{M}_{3}$ generation decreased the number of leaves per plant in the irradiation doses than control plants. Gamma irradiation induces a stimulatory effect in early flowering in $400 \mathrm{~Gy}$ (34.06 \pm 0.26 ) in the second generation. Similarly, in the third generation, the same traits were observed at 400 Gy (41.7 \pm 0.50), but in higher doses, 800 Gy induced late-flowering on $\mathrm{M}_{2}$ and $\mathrm{M}_{3}$ generations. The present result proved that gamma radiation is creating early flowering in consecutive generations. Gamma irradiation can be inducing early flowering in lower doses, while higher doses induced late flowering.

In $\mathrm{M}_{2}$ generation, the gradual increase in the

Table 2. List of morphology and quantitative traits and their description of the measurement

\begin{tabular}{lll}
\hline Growth/Yield trait & Denotation & Method of evaluation \\
\hline Plant height & PH & The height from the base of the plant to the tip of the last leaf \\
\hline Number of Branches per plant & NBP & Count the total number of primary branches per plant \\
\hline Number of leaves per plant & NLP & Count the total number of leaves per plant \\
\hline Days to first flowering & DFF & Count the number of days from seed sown to first flowering \\
\hline Number of fruit cluster per plant & NCP & Count the total number of cluster per plant \\
\hline Number of pods per plant & NPP & Count the number of pods per plant \\
\hline Pod Length & PL & Measure the base to the tip of the pod \\
\hline Number of seeds per pod & NSP & Count the total number of seeds per pod \\
\hline Hundred seed weight & HSW & Count the one hundred seeds randomly and the weighed \\
\hline Seed yield per plant & SYP & Weighing the total number of seeds produced in a plant \\
\hline
\end{tabular}

control plants. Plants treated with 800 Gy gammairradiated doses took more days to first flowering $(41.76 \pm 0.15)$ than in control $(34.16 \pm 0.11)$. The quantitative characters like plant height $(\mathrm{cm})$, the number of branches per plant, the number of leaves number of fruit clusters per plant was noted in 200 Gy $(23.96 \pm 1.25)$. In this study, the number of fruit clusters was significantly positively correlated with plant height $(p<0.05)$, number of branches per plant, number of leaves per plant $(p<0.01)$, and negative 
Table 3. Effects of gamma radiation on quantitative traits of cowpea in $\mathrm{M}_{1}$ generation

\begin{tabular}{ccccccccccc}
\hline Doses (Gy) & PH & NBP & NLP & DFF & NCP & NPP & PL & NSP & HSW (g) & SYP (g) \\
\hline \multirow{3}{*}{ Control } & 60.60 & 6.5 & 107.90 & 34.16 & 19.26 & 39.53 & 15.76 & 16.22 & 10.82 & 35.22 \\
& \pm & \pm & \pm & \pm & \pm & \pm & \pm & \pm & \pm & \pm \\
& 1.08 & 0.24 & 1.19 & 0.11 & 0.66 & 1.12 & 0.20 & 0.23 & 0.03 & 0.85 \\
\hline \multirow{3}{*}{200 Gy } & 57.86 & 5.53 & 103.3 & 35.53 & 18.33 & 35.77 & 14.87 & 14.59 & 9.84 & 31.61 \\
& \pm & \pm & \pm & \pm & \pm & \pm & \pm & \pm & \pm & \pm \\
& 1.21 & 0.22 & 0.87 & 0.17 & 0.58 & 1.35 & 0.24 & 0.19 & 0.05 & 1.76 \\
\hline \multirow{2}{*}{400 Gy } & 53.35 & 5.43 & 98.2 & 36.13 & 18.03 & 31.46 & 14.03 & 14.97 & 9.64 & 26.36 \\
& \pm & \pm & \pm & \pm & \pm & \pm & \pm & \pm & \pm & \pm \\
& 1.04 & 0.18 & 3.09 & 0.19 & 0.566 & 1.71 & 0.18 & 0.28 & 0.14 & 1.47 \\
\hline \multirow{2}{*}{600 Gy } & 51.10 & 4.73 & 95.4 & 38.3 & 14.9 & 24.33 & 12.43 & 13.31 & 8.74 & 20.74 \\
& \pm & \pm & \pm & \pm & \pm & \pm & \pm & \pm & \pm & \pm \\
& 0.79 & 0.14 & 3.61 & 0.12 & 0.66 & 0.97 & 0.25 & 0.17 & 0.04 & 0.60 \\
\hline \multirow{2}{*}{800 Gy } & 45.74 & 3.36 & 90.83 & 41.76 & 11.9 & 18.13 & 8.1 & 10.03 & 8.07 & 14.32 \\
& \pm & \pm & \pm & \pm & \pm & \pm & \pm & \pm & \pm & \pm \\
& 0.68 & 0.17 & 2.47 & 0.15 & 0.53 & 0.84 & 0.26 & 0.26 & 0.04 & 0.38 \\
\hline
\end{tabular}

Data were expressed as mean \pm SE (Standard Error), PH-Plant height, NBP-Number of branches per plant, NLP-Number of leaves per plant, DFF- Days to first flowering, NCP-Number of fruit cluster per plant, NPP-Number of pods per, NSP-Number of seeds per pod plant, PL- Pod length, HSW-Hundred seed weight, SYP- Seed yield per plant.

Table 4. Effects of gamma radiation on quantitative traits of cowpea in $\mathrm{M}_{2}$ generation

\begin{tabular}{|c|c|c|c|c|c|c|c|c|c|c|}
\hline Doses (Gy) & PH & NBP & NLP & DFF & NCP & NPP & PL & NSP & HSW (g) & SYP (g) \\
\hline Control & $\begin{array}{c}60.52 \\
\pm \\
1.63\end{array}$ & $\begin{array}{c}4.50 \\
\pm \\
0.11\end{array}$ & $\begin{array}{c}119.8 \\
\pm \\
2.39\end{array}$ & $\begin{array}{c}36.2 \\
\pm \\
0.37\end{array}$ & $\begin{array}{c}20.93 \\
\pm \\
0.96\end{array}$ & $\begin{array}{c}41.9 \\
\pm \\
1.51\end{array}$ & $\begin{array}{c}14.67 \\
\pm \\
0.15\end{array}$ & $\begin{array}{c}14.7 \\
\pm \\
0.18\end{array}$ & $\begin{array}{c}10.16 \\
\pm \\
0.15\end{array}$ & $\begin{array}{c}36.07 \\
\pm \\
1.46\end{array}$ \\
\hline 200 Gy & $\begin{array}{c}64.64 \\
\pm \\
0.62\end{array}$ & $\begin{array}{c}4.53 \\
\pm \\
0.14\end{array}$ & $\begin{array}{c}126.86 \\
\pm \\
2.65\end{array}$ & $\begin{array}{c}35.1 \\
\pm \\
0.32\end{array}$ & $\begin{array}{c}23.96 \\
\pm \\
1.25\end{array}$ & $\begin{array}{c}45.6 \\
\pm \\
2.04\end{array}$ & $\begin{array}{c}15.63 \\
\pm \\
0.18\end{array}$ & $\begin{array}{c}14.63 \\
\pm \\
0.27\end{array}$ & $\begin{array}{c}10.43 \\
\pm \\
0.15\end{array}$ & $\begin{array}{c}40.13 \\
\pm \\
0.93\end{array}$ \\
\hline 400 Gy & $\begin{array}{c}57.97 \\
\pm \\
1.13\end{array}$ & $\begin{array}{c}4.2 \\
\pm \\
0.25\end{array}$ & $\begin{array}{c}110.2 \\
\pm \\
4.04\end{array}$ & $\begin{array}{c}34.06 \\
\pm \\
0.26\end{array}$ & $\begin{array}{c}21.833 \\
\pm \\
1.55\end{array}$ & $\begin{array}{c}36.3 \\
\pm \\
2.19\end{array}$ & $\begin{array}{c}13.65 \\
\pm \\
0.20\end{array}$ & $\begin{array}{c}13.26 \\
\pm \\
0.33\end{array}$ & $\begin{array}{c}9.86 \\
\pm \\
0.16\end{array}$ & $\begin{array}{c}30.40 \\
\pm \\
2.04\end{array}$ \\
\hline 600 Gy & $\begin{array}{c}55.83 \\
\pm \\
1.91\end{array}$ & $\begin{array}{c}3.9 \\
\pm \\
0.16\end{array}$ & $\begin{array}{c}101.56 \\
\pm \\
1.45\end{array}$ & $\begin{array}{c}35.8 \\
\pm \\
0.35\end{array}$ & $\begin{array}{c}20.733 \\
\pm \\
1.42\end{array}$ & $\begin{array}{c}32.166 \\
\pm \\
1.25\end{array}$ & $\begin{array}{c}13.93 \\
\pm \\
0.27\end{array}$ & $\begin{array}{c}13.1 \\
\pm \\
0.40\end{array}$ & $\begin{array}{c}9.39 \\
\pm \\
0.17\end{array}$ & $\begin{array}{c}27.64 \\
\pm \\
1.07\end{array}$ \\
\hline 800 Gy & $\begin{array}{c}55.64 \\
\pm \\
1.75\end{array}$ & $\begin{array}{c}4.1 \\
\pm \\
0.16\end{array}$ & $\begin{array}{c}95.66 \\
\pm \\
2.64\end{array}$ & $\begin{array}{c}38.43 \\
\pm \\
0.40\end{array}$ & $\begin{array}{c}17.6 \\
\pm \\
0.77\end{array}$ & $\begin{array}{c}22.06 \\
\pm \\
1.17\end{array}$ & $\begin{array}{c}13.49 \\
\pm \\
0.22\end{array}$ & $\begin{array}{c}13.00 \\
\pm \\
0.38\end{array}$ & $\begin{array}{c}9.91 \\
\pm \\
0.12\end{array}$ & $\begin{array}{c}19.68 \\
\pm \\
0.96\end{array}$ \\
\hline
\end{tabular}

Data were expressed as mean \pm SE (Standard Error), PH-Plant height, NBP-Number of branches per plant, NLP-Number of leaves per plant, DFF- Days to first flowering, NCP-Number of fruit cluster per plant, NPP-Number of pods per, NSP-Number of seeds per pod plant, PL- Pod length, HSW-Hundred seed weight, SYP- Seed yield per plant.

Table 5. Effects of gamma radiation on quantitative traits of cowpea in $\mathrm{M}_{3}$ generation

\begin{tabular}{|c|c|c|c|c|c|c|c|c|c|c|}
\hline Doses (Gy) & PH & NBP & NLP & DFF & NCP & NPP & PL & NSP & HSW (g) & SYP (g) \\
\hline \multirow{3}{*}{ Control } & 59.02 & 5.16 & 261.16 & 43.83 & 39.3 & 48.4 & 13.05 & 12.1 & 11.29 & 41.25 \\
\hline & \pm & \pm & \pm & \pm & \pm & \pm & \pm & \pm & \pm & \pm \\
\hline & & & & & & & & & & \\
\hline \multirow[b]{2}{*}{200 Gy } & 62.21 & 4.8 & 260.33 & 43.53 & 37.36 & 55.3 & 13.61 & 12.46 & 11.91 & 48.56 \\
\hline & 2.60 & 0.29 & $\begin{array}{c} \pm \\
18.74\end{array}$ & 0.20 & 3.25 & $\begin{array}{c} \pm \\
3.27\end{array}$ & 0.29 & 0.37 & 0.11 & 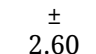 \\
\hline \multirow{3}{*}{$400 \mathrm{~Gy}$} & 54.46 & 4.2 & 166.76 & 41.7 & 26.5 & 50.03 & 13.52 & 13.23 & 12.71 & 44.23 \\
\hline & \pm & \pm & \pm & \pm & \pm & \pm & \pm & \pm & \pm & \pm \\
\hline & 2.25 & 0.26 & 12.11 & 0.50 & 2.36 & 4.03 & 0.15 & 0.32 & 0.11 & 3.11 \\
\hline \multirow{3}{*}{600 Gy } & 52.07 & 4.43 & 170.23 & 41.96 & 28.7 & 54.16 & 12.72 & 12.00 & 11.90 & 38.31 \\
\hline & \pm & \pm & \pm & \pm & \pm & \pm & \pm & \pm & \pm & \pm \\
\hline & 1.79 & 0.20 & 9.41 & 0.60 & 1.64 & 2.92 & 0.21 & 0.34 & 0.12 & 2.25 \\
\hline \multirow{3}{*}{800 Gy } & 50.73 & 4.5 & 170.3 & 46.73 & 24.66 & 38.53 & 11.58 & 9.83 & 11.65 & 29.49 \\
\hline & \pm & \pm & \pm & \pm & \pm & \pm & \pm & \pm & \pm & \pm \\
\hline & 1.78 & 0.19 & 12.92 & 0.51 & 1.59 & 2.50 & 0.26 & 0.39 & 0.11 & 2.03 \\
\hline
\end{tabular}

Data were expressed as mean \pm SE (Standard Error), PH-Plant height, NBP-Number of branches per plant, NLP-Number of leaves per plant, DFF- Days to first flowering, NCP-Number of fruit cluster per plant, NPP-Number of pods per, NSP-Number of seeds per pod plant, PL- Pod length, HSW-Hundred seed weight, SYP- Seed yield per plant.

correlation obtained in days to first flowering (Table 7). On the contrary, the $\mathrm{M}_{3}$ generation showed decreased fruit clusters in all the doses compared to control. A positive mean value was shifted in the number of pods per plant in both $\mathrm{M}_{2}$ and $\mathrm{M}_{3}$ generations. The increasing number of pods per plant was observed at $200 \mathrm{~Gy}$ in $\mathrm{M}_{2}(45.6 \pm 2.04)$ and $\mathrm{M}_{3}$ $(55.3 \pm 3.27)$ generations. The pod length was also significantly increased in the second mutagenic generation compared to the third generation. The number of seeds per pod decreased in the second generation, with increasing doses of gamma irradiation and maximum decreased at 800 Gy (13 \pm $0.38)$. The result confirmed that the number of seeds per pod had a strong positive correlation $(p<0.01)$ to pod length (Table 6). Whereas in $\mathrm{M}_{3}$ generation, a substantial increase in the number of seeds per plant observed at $400 \mathrm{~Gy}(13.23 \pm 0.32)$ when compared to control and other doses respectively. Gamma irradiation revealed a considerable enhancement in yield traits of both second and third mutagenic generations of cowpea. In $\mathrm{M}_{2}$ generation, the 
Table 6. Pearson's correlation coefficients of different quantitative traits of $\mathrm{M}_{1}$ generation

\begin{tabular}{|c|c|c|c|c|c|c|c|c|c|c|}
\hline & PH & NBP & NLP & DFF & NCP & NPP & PL & NSP & HSW & SYP \\
\hline PH & 1 & $.424^{* *}$ & $.248^{* *}$ & $-.634^{* *}$ & $.373^{* *}$ & $.528^{* *}$ & $.545^{* *}$ & $.594^{* *}$ & $.612^{* *}$ & $.646^{* *}$ \\
\hline NBP & & 1 & $.376^{* *}$ & $-.655^{* *}$ & $.452^{* *}$ & $.514^{* *}$ & $.644^{* *}$ & $.648^{* *}$ & $.525^{* *}$ & $.590^{* *}$ \\
\hline NLP & & & 1 & $-.342^{* *}$ & $.316^{* *}$ & $.283^{* *}$ & $.284^{* *}$ & $.276^{* *}$ & $.312^{* *}$ & $.403^{* *}$ \\
\hline DFF & & & & 1 & $-.630^{* *}$ & $-.722^{* *}$ & $-.794^{* *}$ & $-.872^{* *}$ & $-.733^{* *}$ & $-.843^{* * 1}$ \\
\hline NCP & & & & & 1 & $.708^{* *}$ & $.506^{* *}$ & $.543^{* *}$ & $.491^{* *}$ & $.549^{* *}$ \\
\hline NPP & & & & & & 1 & $.614^{* *}$ & $.660^{* *}$ & $.754^{* *}$ & $.725^{* *}$ \\
\hline PL & & & & & & & 1 & $.894^{* *}$ & $.625^{* *}$ & $.724^{* *}$ \\
\hline NSP & & & & & & & & 1 & $.676^{* *}$ & $.767^{* *}$ \\
\hline HSW & & & & & & & & & 1 & $.744^{* *}$ \\
\hline SYP & & & & & & & & & & 1 \\
\hline
\end{tabular}

** indicate significance of $\mathrm{p}$ values of $<0.001$ level

PH-Plant height, NBP-Number of branches per plant, NLP-Number of leaves per plant, DFF- Days to first flowering, NCP-Number of fruit cluster per plant, NPP-Number of pods per, NSP-Number of seeds per pod plant, PL- Pod length, HSW-Hundred seed weight, SYP- Seed yield per plant.

Table 7. Pearson's correlation coefficients of different quantitative traits of $\mathrm{M}_{2}$ generation

\begin{tabular}{|c|c|c|c|c|c|c|c|c|c|c|}
\hline & PH & NBP & NLP & DFF & NCP & NPP & PL & NSP & HSW & SYP \\
\hline $\mathrm{PH}$ & 1 & & & & & & & & & \\
\hline NBP & $.189^{*}$ & 1 & & & & & & & & \\
\hline NLP & $.314^{* *}$ & $.537^{* * *}$ & 1 & & & & & & & \\
\hline DFF & -.070 & -.009 & $-.213^{* *}$ & 1 & & & & & & \\
\hline $\mathrm{NCP}$ & $.195^{*}$ & $.648^{* *}$ & $.480^{* *}$ & -.096 & 1 & & & & & \\
\hline NPP & $.341^{* *}$ & $.570^{* *}$ & $.583^{* *}$ & $-.230^{* *}$ & $.651^{* *}$ & 1 & & & & \\
\hline PL & $.256^{* *}$ & $.174^{*}$ & $.303^{* *}$ & $-.194^{*}$ & $.270^{* *}$ & $.331^{* *}$ & 1 & & & \\
\hline NSP & .098 & .160 & $.223^{* *}$ & -.059 & $.165^{*}$ & $.294^{* *}$ & $.668^{* *}$ & 1 & & \\
\hline HSW & .130 & $.259^{* * *}$ & $.261^{* *}$ & .041 & $.188^{*}$ & $.278^{* *}$ & $.181^{*}$ & $.193^{*}$ & 1 & \\
\hline SYP & $.325^{* *}$ & $.518^{* *}$ & $.583^{* * *}$ & $-.205^{*}$ & $.546^{* *}$ & $.874^{* * *}$ & $.367^{* *}$ & $.303^{* *}$ & $.271^{* *}$ & 1 \\
\hline
\end{tabular}

* and ** indicate significant at the $\mathrm{p}<0.05$ and 0.01 level

PH-Plant height, NBP-Number of branches per plant, NLP-Number of leaves per plant, DFF- Days to first flowering, NCP-Number of fruit cluster per plant, NPP-Number of pods per, NSP-Number of seeds per pod plant, PL- Pod length, HSW-Hundred seed weight, SYP- Seed yield per plant.

enhancement of the 100 seed weight was noted in 200 Gy (10.43 \pm 0.15$)$, whereas other doses showed decreased level compared to control. In $\mathrm{M}_{3}$ generation, 100 seed weight was higher in all mutagenic treatments than control. The increase of 100 seed weight was observed at 400 Gy $(12.71 \pm$ $0.11)$, followed by $200 \mathrm{~Gy}(11.91 \pm 0.11), 600 \mathrm{~Gy}(11.90$ $\pm 0.12)$, and $800 \mathrm{~Gy}(11.65 \pm 0.11)$. In the $\mathrm{M}_{3}$ generation, the 100 seed weight was enhanced than the $\mathrm{M}_{2}$ generation. In the second generation, a lower dose of gamma rays increased the seed yield at 200 Gy (40.13 \pm 0.93) and decreased in other doses compared to control. Irradiation doses of $200 \mathrm{~Gy}$ $(48.56 \pm 2.60)$ and $400 \mathrm{~Gy}(44.23 \pm 3.11)$ increased the seed yield while other doses were decreased compared to control of the third generation. Seed yield revealed a significant positive correlation to the plant height, number of branches per plant, number of leaves per plant, number of fruit cluster per plant, number of pods per plant, and pod length. Furthermore, a significant negative correlation obtained for days to first flowering, so the yield was increased (Table 8).

\section{SCoT marker}

In the present investigation, the genetic variation among $M_{1}, M_{2}$, and $M_{3}$ generations of cowpea tested with varied doses of gamma irradiation and control were analysed by the SCoT marker. Among the eight primers tested, seven primers were amplified and found reproducible, whereas no amplification was detected in the primer SCoT09 for all three generations. In all generations, 222 bands were scored, of which 133 were polymorphic (Table 9). The $\%$ of polymorphic bands in each primer differed from $3.03-96.07 \%$, with an average of $67.10 \%$. The polymorphic bands per primer range between 2 (SCOT01) to 49 (SCOT06), within an average of $19 \%$, and the number of bands varied between generations. The SCoT01 primer obtained more bands than other primers, whereas a minimum number of amplicons were observed at SCoT10. The highest polymorphic bands were observed in SCoT06 (49), whilst the lowest polymorphic band was noted in SCoT01 (2) primer. The SCoT03 and SCoT08 primers detected the absence of bands for $\mathrm{M}_{3}$ generation, whereas it was amplified for $\mathrm{M}_{1}$ and $\mathrm{M}_{2}$ generations. In $\mathrm{M}_{2}$ generation, all the primers were amplified; however SCoT08 primer was not amplified in $\mathrm{M}_{3}$ generation because the primer site (ATG) does not bind DNA samples, degradation of chemicals, buffer solutions, polymerase enzymes etc.

\section{Genetic diversity}

Table 10 showed the genetic variation of cowpea among $\mathrm{M}_{1}, \mathrm{M}_{2}, \mathrm{M}_{3}$ generations. In $\mathrm{M}_{1}$ generation, the number of different alleles $(\mathrm{Na})$ varies between $1.143 \pm 0.404$ to $2 \pm 0.001$, the number of effective alleles $(\mathrm{Ne})$ varied from $1.270 \pm 0.117$ to $1.443 \pm$ 0.124 . The Shannon's Information Index $(I)$ were ranged from $0.268 \pm 0.106$ to $0.434 \pm 0.073$, Expected heterozygosity ( $\mathrm{He}$ ) ranged from $0.173 \pm$ 0.072 to $0.277 \pm 0.059$, and unbiased Expected Heterozygosity $(\mathrm{uHe})$ between $0.182 \pm 0.075$ to $0.291 \pm 0.063$. The higher dose (800 Gy) of gamma irradiation showed high genetic diversity than other doses and control. In $\mathrm{M}_{2}$ generation, $\mathrm{Na}$ value ranged from $1.429 \pm 0.369$ to $2.000 \pm 0.001$, Ne lowest to highest ranged from $1.133 \pm 0.050$ to 1.386 $\pm 0.063, I$ minimum to maximum value between $0.198 \pm 0.062$ to $0.433 \pm 0.047$, He ranged from 0.108 \pm 0.037 to $0.269 \pm 0.036$ and $u H e$ minimum to 
Table 8. Pearson's correlation coefficients of different quantitative traits of $\mathrm{M}_{3}$ generation

\begin{tabular}{|c|c|c|c|c|c|c|c|c|c|c|}
\hline & PH & NBP & NLP & DFF & NCP & NPP & PL & NSP & HSW & SYP \\
\hline$\overline{\mathrm{PH}}$ & 1 & & & & & & & & & \\
\hline NBP & $.384^{* *}$ & 1 & & & & & & & & \\
\hline NLP & $.427^{* *}$ & $.724^{* *}$ & 1 & & & & & & & \\
\hline$\overline{\text { DFF }}$ & -.061 & -.032 & -.101 & 1 & & & & & & \\
\hline NCP & $.254^{* *}$ & $.444^{* *}$ & $.599^{* *}$ & $-.183^{*}$ & 1 & & & & & \\
\hline NPP & $.254^{* *}$ & $.354^{* *}$ & $.315^{* *}$ & $-.357^{* *}$ & $.576^{* *}$ & 1 & & & & \\
\hline PL & $.221^{* *}$ & -.047 & .127 & -.143 & .028 & .104 & 1 & & & \\
\hline NSP & $.169^{*}$ & -.108 & .045 & $-.189^{*}$ & .005 & .059 & $.858^{* *}$ & 1 & & \\
\hline HSW & -.048 & -.097 & -.124 & $-.169^{*}$ & $-.186^{*}$ & .054 & .152 & $.248^{* *}$ & 1 & \\
\hline SYP & $.286^{* *}$ & $.276^{* *}$ & $.314^{* *}$ & $-.230^{* *}$ & $.502^{* *}$ & $.798^{* *}$ & $.182^{*}$ & .111 & .100 & 1 \\
\hline
\end{tabular}

* and ${ }^{* *}$ indicate significance at the $\mathrm{p}<0.05$ and 0.01 level respectively

PH-Plant height, NBP-Number of branches per plant, NLP-Number of leaves per plant, DFF- Days to first flowering, NCP-Number of fruit cluster per plant, NPP-Number of pods per, NSP-Number of seeds per pod plant, PL- Pod length, HSW-Hundred seed weight, SYP- Seed yield per plant.

Table 9. SCoT primers used in $\mathrm{M}_{1}, \mathrm{M}_{2}$, and $\mathrm{M}_{3}$ generations of cowpea under the effects of gamma irradiation

\begin{tabular}{|c|c|c|c|c|c|c|c|c|c|c|c|c|c|c|c|c|c|c|}
\hline \multirow{3}{*}{$\begin{array}{c}\text { No. of } \\
\text { primers }\end{array}$} & \multicolumn{15}{|c|}{ Generations } & \multirow{3}{*}{$\begin{array}{l}\text { Total } \\
\text { no. of } \\
\text { bands }\end{array}$} & \multirow{3}{*}{$\begin{array}{l}\text { No. of } \\
\text { polym } \\
\text { orphic } \\
\text { bands }\end{array}$} & \multirow{3}{*}{$\begin{array}{c}\text { Percen } \\
\text { tage } \\
(\%) \text { of } \\
\text { polym } \\
\text { orphis } \\
\text { m }\end{array}$} \\
\hline & \multicolumn{5}{|c|}{$\mathbf{M}_{1}$} & \multicolumn{5}{|c|}{$\mathbf{M}_{2}$} & \multicolumn{5}{|c|}{$\mathbf{M}_{3}$} & & & \\
\hline & $\mathrm{CPCM}_{1}$ & $\mathrm{CP}_{2} \mathrm{M}_{1}$ & $\mathrm{CP} \mathrm{M}_{1}$ & $\mathrm{CP} \mathrm{M}_{1}$ & $\mathrm{CP} \mathrm{M}_{1}$ & $\mathrm{CPCM}_{2}$ & $\mathrm{CP} \mathrm{M}_{2}$ & $\mathbf{C P}_{4} \mathbf{M}_{2}$ & $\mathrm{CP} \mathrm{M}_{2}$ & $\mathrm{CP} \mathrm{M}_{2}$ & $\mathrm{CPCM}_{3}$ & $\mathrm{CP} 2 \mathrm{M}_{3}$ & $\mathrm{CP} \mathrm{M}_{3}$ & $\mathrm{CP}_{6} \mathrm{M}_{3}$ & $\mathrm{CP} 8 \mathrm{M}_{3}$ & & & \\
\hline SCOT01 & 5 & 4 & 5 & 5 & 6 & 1 & 4 & 4 & 6 & 3 & 0 & 5 & 6 & 6 & 6 & 66 & 2 & 3.03 \\
\hline SCOT02 & 1 & 1 & 3 & 5 & 4 & 1 & 3 & 2 & 2 & 2 & 0 & 0 & 0 & 0 & 4 & 28 & 21 & 75.00 \\
\hline SCOT03 & 0 & 3 & 1 & 1 & 2 & 0 & 1 & 1 & 1 & 0 & 0 & 0 & 0 & 0 & 0 & 10 & 8 & 80.00 \\
\hline SCOT06 & 4 & 5 & 4 & 5 & 6 & 3 & 4 & 0 & 3 & 4 & 3 & 3 & 3 & 0 & 4 & 51 & 49 & 96.07 \\
\hline SCOT07 & 4 & 4 & 2 & 3 & 3 & 2 & 2 & 3 & 3 & 2 & 2 & 2 & 2 & 2 & 2 & 38 & 33 & 86.84 \\
\hline SCOT08 & 0 & 0 & 0 & 0 & 1 & 0 & 4 & 2 & 3 & 1 & 0 & 0 & 0 & 0 & 0 & 11 & 5 & 45.45 \\
\hline SCOT10 & 0 & 0 & 0 & 0 & 1 & 1 & 3 & 0 & 0 & 0 & 0 & 4 & 4 & 0 & 5 & 18 & 15 & 83.33 \\
\hline Total & 14 & 17 & 15 & 19 & 23 & 8 & 21 & 12 & 18 & 12 & 5 & 14 & 15 & 8 & 21 & 222 & 133 & 67.10 \\
\hline Average & & & & & & & & & & & & & & & & 31.71 & 19.00 & \\
\hline
\end{tabular}

CPC-Cowpea Control, CP2-Cowpea 200Gy, CP4-Cowpea 400 Gy, CP6-Cowpea 600 Gy, CP8-Cowpea 800 Gy

maximum value from $0.112 \pm 0.039$ to $0.283 \pm 0.038$ were observed control and gamma irradiated doses. However, 200 Gy irradiation doses induced more genetic variability compared to control. Whereas in $\mathrm{M}_{3}$ generation, genetic diversity showed lowest to highest $\mathrm{Na}$ value from $0.571 \pm$ 0.369 to $1.429 \pm 0.369$, Ne lowest to highest value range from $1.087 \pm 0.058$ to $1.412 \pm 0.129$, minimum to maximum $I$ ranged from $0.112 \pm 0.073$ to $0.381 \pm$ 0.105 , He value ranged from $0.066 \pm 0.044$ to 0.182 \pm 0.072 and $u H e$ minimum to maximum value between $0.069 \pm 0.046$ to $0.266 \pm 0.076$ were noted in control and gamma treated doses. Here, in all three generations, irradiated doses are induced high genetic variability compared to control.

\section{Genetic distance}

Table 11 showed Nei's unbiased pairwise genetic distance of cowpea genotypes calculated in three successive generations treated by different gamma irradiation doses. In $\mathrm{M}_{1}$ generation, the higher genetic distance was observed in $400 \mathrm{~Gy}$ and $600 \mathrm{~Gy}$ $(0.705)$ and low genetic distance obtained in control and $800 \mathrm{~Gy}(0.377)$. Whereas in $\mathrm{M}_{2}$ generation, the high distance was observed between $400 \mathrm{~Gy}$ and 600 Gy (0.758), 600 Gy and 800 Gy (0.758) showed the same distance value, and the low genetic distance was observed at the control and $400 \mathrm{~Gy}(0.4)$. In $\mathrm{M}_{3}$ generation, a high genetic distance was observed at $200 \mathrm{~Gy}$ and $400 \mathrm{~Gy}(0.896)$, a low distance value at the control and 800 Gy (0.2307). Compared to all the three generations, $\mathrm{M}_{2}$ generations showed more genetic distance.

\section{Analysis of Molecular Variance (AMOVA) and Dendrogram}

Analysis of molecular variance (AMOVA) results showed that genetic difference (5\%) was observed among the populations, whereas $95 \%$ variation was observed within populations (Table 12) for all three generations. The phylogenic tree was used to visualise the genetic variations in three generations of the different doses of gamma irradiation. The dendrogram of three generations was divided into four clusters (Fig. 2). Cluster I consists of $\mathrm{M}_{2}$ generation alone, $400 \mathrm{~Gy}$ and $600 \mathrm{~Gy}$ shared a common sister group, and 200 Gy showed a common ancestor for both doses of gamma irradiation (400 Gy and 600 Gy). Cluster II and III shared a common internode consisting of $\mathrm{M}_{1}$ and $\mathrm{M}_{3}$ generations. Besides, Cluster II consists of 200 Gy, 400 Gy, 600 Gy and $800 \mathrm{~Gy}$, along with control. The $200 \mathrm{~Gy}$ and control shared a common branch and $400 \mathrm{~Gy}$ and 800 Gy shared a common node. Cluster III was showed proximity with $800 \mathrm{~Gy}, 200 \mathrm{~Gy}$ and $400 \mathrm{~Gy}$. Cluster IV consists of $\mathrm{M}_{3}$ control, and these are the common ancestor for all the Operational Taxonomic Units (OTU).

\section{Principal Coordinates Analysis (PCoA)}

PCoA analysis showed the genetic relationships between the generations of cowpea by the effects of gamma irradiation (Fig. 3). The cowpea genotypes were divided into 5 groups. It consists of group I (6 doses), group II (7 doses), group III (5 doses), group IV (10 doses) and group V (10 doses) were grouped and individual doses were scattered from the grouped. 
The first, second and third axes represented $31.90 \%$, $53.14 \%$, and $69.09 \%$ of the cumulative variation. horse gram (42). Whereas the days to first flowering were delayed in all the irradiated seeds, particularly

Table 10. Genetic diversity analysis in $\mathrm{M}_{1}, \mathrm{M}_{2}, \mathrm{M}_{3}$ generations of cowpea revealed by SCoT primers

\begin{tabular}{|c|c|c|c|c|c|}
\hline Samples/Populations & $\mathrm{Na} \pm \mathrm{SE}$ & $\mathrm{Ne} \pm \mathrm{SE}$ & $\mathbf{I} \pm \mathbf{S E}$ & $\mathrm{He} \pm \mathrm{SE}$ & $\mathbf{u H e} \pm \mathrm{SE}$ \\
\hline $\mathrm{CPCM}_{1}$ & $1.143 \pm 0.404$ & $1.270 \pm 0.117$ & $0.268 \pm 0.106$ & $0.173 \pm 0.072$ & $0.182 \pm 0.075$ \\
\hline $\mathrm{CP} 2 \mathrm{M}_{1}$ & $1.429 \pm 0.369$ & $1.323 \pm 0.109$ & $0.331 \pm 0.098$ & $0.212 \pm 0.066$ & $0.223 \pm 0.070$ \\
\hline $\mathrm{CP} 4 \mathrm{M}_{1}$ & $1.429 \pm 0.369$ & $1.280 \pm 0.103$ & $0.303 \pm 0.092$ & $0.189 \pm 0.062$ & $0.199 \pm 0.066$ \\
\hline $\mathrm{CP} 6 \mathrm{M}_{1}$ & $1.429 \pm 0.369$ & $1.372 \pm 0.128$ & $0.352 \pm 0.106$ & $0.230 \pm 0.074$ & $0.243 \pm 0.077$ \\
\hline $\mathrm{CP} 8 \mathrm{M}_{1}$ & $2.000 \pm 0.001$ & $1.443 \pm 0.124$ & $0.434 \pm 0.073$ & $0.277 \pm 0.059$ & $0.291 \pm 0.063$ \\
\hline $\mathrm{CPCM}_{2}$ & $1.429 \pm 0.369$ & $1.133 \pm 0.050$ & $0.198 \pm 0.062$ & $0.108 \pm 0.037$ & $0.112 \pm 0.039$ \\
\hline $\mathrm{CP} 2 \mathrm{M}_{2}$ & $2.000 \pm 0.001$ & $1.386 \pm 0.063$ & $0.433 \pm 0.047$ & $0.269 \pm 0.036$ & $0.283 \pm 0.038$ \\
\hline $\mathrm{CP} 4 \mathrm{M}_{2}$ & $1.429 \pm 0.369$ & $1.212 \pm 0.075$ & $0.265 \pm 0.079$ & $0.157 \pm 0.050$ & $0.165 \pm 0.053$ \\
\hline $\mathrm{CP} 6 \mathrm{M}_{2}$ & $1.714 \pm 0.286$ & $1.334 \pm 0.105$ & $0.362 \pm 0.079$ & $0.224 \pm 0.056$ & $0.236 \pm 0.059$ \\
\hline $\mathrm{CP} 8 \mathrm{M}_{2}$ & $1.429 \pm 0.369$ & $1.212 \pm 0.075$ & $0.265 \pm 0.079$ & $0.157 \pm 0.050$ & $0.165 \pm 0.053$ \\
\hline $\mathrm{CPCM}_{3}$ & $0.571 \pm 0.369$ & $1.087 \pm 0.058$ & $0.112 \pm 0.073$ & $0.066 \pm 0.044$ & $0.069 \pm 0.046$ \\
\hline $\mathrm{CP} 2 \mathrm{M}_{3}$ & $1.143 \pm 0.404$ & $1.265 \pm 0.108$ & $0.274 \pm 0.102$ & $0.175 \pm 0.067$ & $0.184 \pm 0.071$ \\
\hline $\mathrm{CP} 4 \mathrm{M}_{3}$ & $1.143 \pm 0.404$ & $1.288 \pm 0.125$ & $0.282 \pm 0.106$ & $0.182 \pm 0.072$ & $0.192 \pm 0.075$ \\
\hline $\mathrm{CP} 6 \mathrm{M}_{3}$ & $0.571 \pm 0.369$ & $1.157 \pm 0.123$ & $0.142 \pm 0.098$ & $0.093 \pm 0.067$ & $0.098 \pm 0.071$ \\
\hline $\mathrm{CP} 8 \mathrm{M}_{3}$ & $1.429 \pm 0.369$ & $1.412 \pm 0.129$ & $0.381 \pm 0.105$ & $0.252 \pm 0.073$ & $0.266 \pm 0.076$ \\
\hline Total & $1.352 \pm 0.092$ & $1.278 \pm 0.027$ & $0.293 \pm 0.023$ & $0.184 \pm 0.016$ & $0.194 \pm 0.016$ \\
\hline
\end{tabular}

Na-Number of different alleles, Ne-Number of effective alleles, I-Shannon's information Index, He-Expected heterozygosity, uHe-unbiased Expected heterozygosity. CPC-Cowpea Control, CP2-Cowpea 200 Gy, CP4-Cowpea 400 Gy, CP6-Cowpea 600 Gy, CP8-Cowpea 800 Gy

Table 11. Nei's unbiased pair wise genetic distance values recorded in $\mathrm{M}_{1}, \mathrm{M}_{2}, \mathrm{M}_{3}$ generations of cowpea treated with different doses of gamma irradiation

\begin{tabular}{|c|c|c|c|c|c|c|c|c|c|c|c|c|c|c|c|}
\hline Doses & $\mathrm{CPCM}_{1}$ & $\mathrm{CP}_{2 M_{1}}$ & $\mathrm{CP} \mathrm{M}_{1}$ & $\mathrm{CP} \mathrm{M}_{1}$ & $\mathrm{CP} 8 \mathrm{M}_{1}$ & $\mathrm{CPCM}_{2}$ & $\mathrm{CP}_{2 \mathrm{M}_{2}}$ & $\mathrm{CP}_{4} \mathrm{M}_{2}$ & $\mathrm{CP} \mathrm{M}_{2}$ & $\mathrm{CP} \mathrm{M}_{2}$ & $\mathrm{CPCM}_{3}$ & $\mathrm{CP} 2 \mathrm{M}_{3}$ & $\mathrm{CP}_{4} \mathrm{M}_{3}$ & $\mathrm{CP}_{6} \mathrm{M}_{3}$ & $\mathrm{CP} \mathrm{M}_{3}$ \\
\hline $\mathrm{CPCM}_{1}$ & $* * *$ & 0.6451 & 0.5517 & 0.4242 & 0.3778 & 0.1818 & 0.3428 & 0.3846 & 0.4516 & 0.4615 & 0.2105 & 0.5000 & 0.6206 & 0.3636 & 0.5714 \\
\hline$\overline{\mathrm{CP} 2 \mathrm{M}_{1}}$ & & $* * *$ & 0.6875 & 0.5555 & 0.5000 & 0.3200 & 0.4210 & 0.4137 & 0.4705 & 0.4827 & 0.1818 & 0.4516 & 0.3750 & 0.3200 & 0.5263 \\
\hline $\mathrm{CP} 4 \mathrm{M}_{1}$ & & & $* * *$ & 0.7058 & 0.6842 & 0.3478 & 0.3333 & 0.3703 & 0.5000 & 0.5185 & 0.2000 & 0.5517 & 0.4666 & 0.4347 & 0.6666 \\
\hline$\overline{\mathrm{CP} 6 \mathrm{M}_{1}}$ & & & & $* * *$ & 0.6666 & 0.3703 & 0.4000 & 0.3225 & 0.4444 & 0.5161 & 0.1666 & 0.4242 & 0.4117 & 0.3703 & 0.5500 \\
\hline CP8 $\mathrm{M}_{1}$ & & & & & $* * *$ & 0.3871 & 0.4545 & 0.4571 & 0.6000 & 0.5714 & 0.2857 & 0.3783 & 0.3684 & 0.3871 & 0.5454 \\
\hline$\overline{\mathrm{CPCM}_{2}}$ & & & & & & $* * *$ & 0.4827 & 0.4000 & 0.4800 & 0.7000 & 0.4615 & 0.2727 & 0.2608 & 0.2500 & 0.3448 \\
\hline $\mathrm{CP} 2 \mathrm{M}_{2}$ & & & & & & & $* * *$ & 0.5454 & 0.7368 & 0.6060 & 0.1538 & 0.2857 & 0.3888 & 0.2069 & 0.5238 \\
\hline$\overline{\mathrm{CP}} 4 \mathrm{M}_{2}$ & & & & & & & & $* * *$ & 0.7586 & 0.5833 & 0.1176 & 0.1538 & 0.2222 & 0.4000 & 0.3636 \\
\hline CP6 M 2 & & & & & & & & & $* * *$ & 0.7586 & 0.1818 & 0.3225 & 0.3750 & 0.4000 & 0.4736 \\
\hline $\mathrm{CP} 8 \mathrm{M}_{2}$ & & & & & & & & & & $* * *$ & 0.3529 & 0.3076 & 0.3703 & 0.3000 & 0.4242 \\
\hline $\mathrm{CPCM}_{3}$ & & & & & & & & & & & $* * *$ & 0.3157 & 0.3000 & 0.3076 & 0.2307 \\
\hline $\mathrm{CP} 2 \mathrm{M}_{3}$ & & & & & & & & & & & & $* * *$ & 0.8965 & 0.5454 & 0.7428 \\
\hline $\mathrm{CP} 4 \mathrm{M}_{3}$ & & & & & & & & & & & & & $* * *$ & 0.5217 & 0.7222 \\
\hline $\mathrm{CP} 6 \mathrm{M}_{3}$ & & & & & & & & & & & & & & $* * *$ & 0.4137 \\
\hline $\mathrm{CP} 8 \mathrm{M}_{3}$ & & & & & & & & & & & & & & & $* * *$ \\
\hline
\end{tabular}

CPC-Cowpea Control, CP2-Cowpea 200Gy, CP4-Cowpea 400 Gy, CP6-Cowpea 600 Gy, CP8-Cowpea 800 Gy

Table 12. Analysis of molecular variance (AMOVA) in $\mathrm{M}_{1}, \mathrm{M}_{2}, \mathrm{M}_{3}$ generations of cowpea using SCoT primer

\begin{tabular}{ccccc}
\hline Source & df & SS & MS & Est.Var \\
\hline Among populations & 14 & 21.133 & 1.510 & 0.050 \\
Variation (\%)
\end{tabular}

df- Degree of freedom, SS-Sum of squares deviation, MS- Mean of squared deviation, Est. Var.- Estimates of variance, \%-Percentage of variation.

\section{Discussion}

Mutation breeding is a promising tool to induce genetic variability in quantitative and qualitative traits in crops. Gamma irradiation is the best physical mutagen in plant breeding technique, and it has been beneficial for the breed in several pulse crops such as mung bean (31), peanut (32), chickpea (33), cowpea (34) and pigeon pea (35). In this study, the $\mathrm{M}_{1}$ results showed that the increase of gamma radiation dose gradually decreased morphological and quantitative traits compared to control (Table 3). The present results reveal that gamma irradiation might induce physiological activity disturbances, arrest the cell division, change or inhibit enzyme activity. Similar results were observed in many crops such as cowpea (36-38), black gram $(11,39,40)$, soybean (41) and in 800 Gy, which took more days (41.76 \pm 0.15) compared to control. Besides, gamma irradiationinduced the delay of days to the first flower in the $\mathrm{M}_{1}$ generation of cowpea (38). The higher dose of gamma rays affected the physiological process, which leads to induce late flowering. Physiological disproportion and different forms of chromosomal distortion could be the leading causes of the decrease in plant survival (43).

The present results depict that the $\mathrm{M}_{2}$ and $\mathrm{M}_{3}$ generations obtained enhancement of yield and yield-related components of cowpea under gamma radiation treatment. In $\mathrm{M}_{2}$ and $\mathrm{M}_{3}$ generations, the plant height was increased at 200 Gy than control. The lower doses of gamma rays induced the plant height due to the expansion of cell division, altering metabolic growth that influences the 


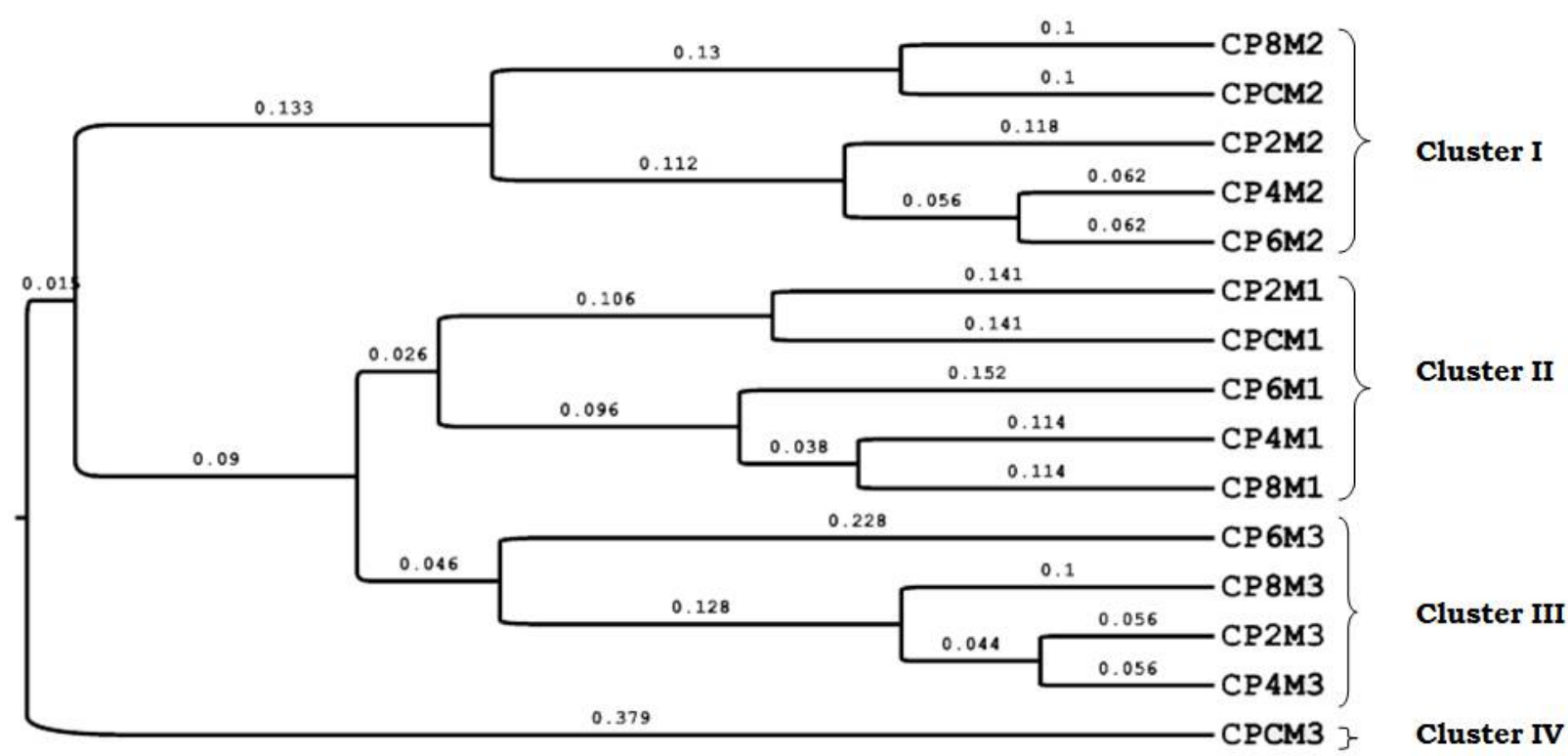

Fig. 2. Dendrogram of cowpea analysis by using UPGMA cluster analysis based on the genetic similarities coefficient. CPC-Cowpea Control, CP2-Cowpea 200Gy, CP4-Cowpea 400 Gy, CP6-Cowpea 600 Gy, CP8-Cowpea 800 Gy

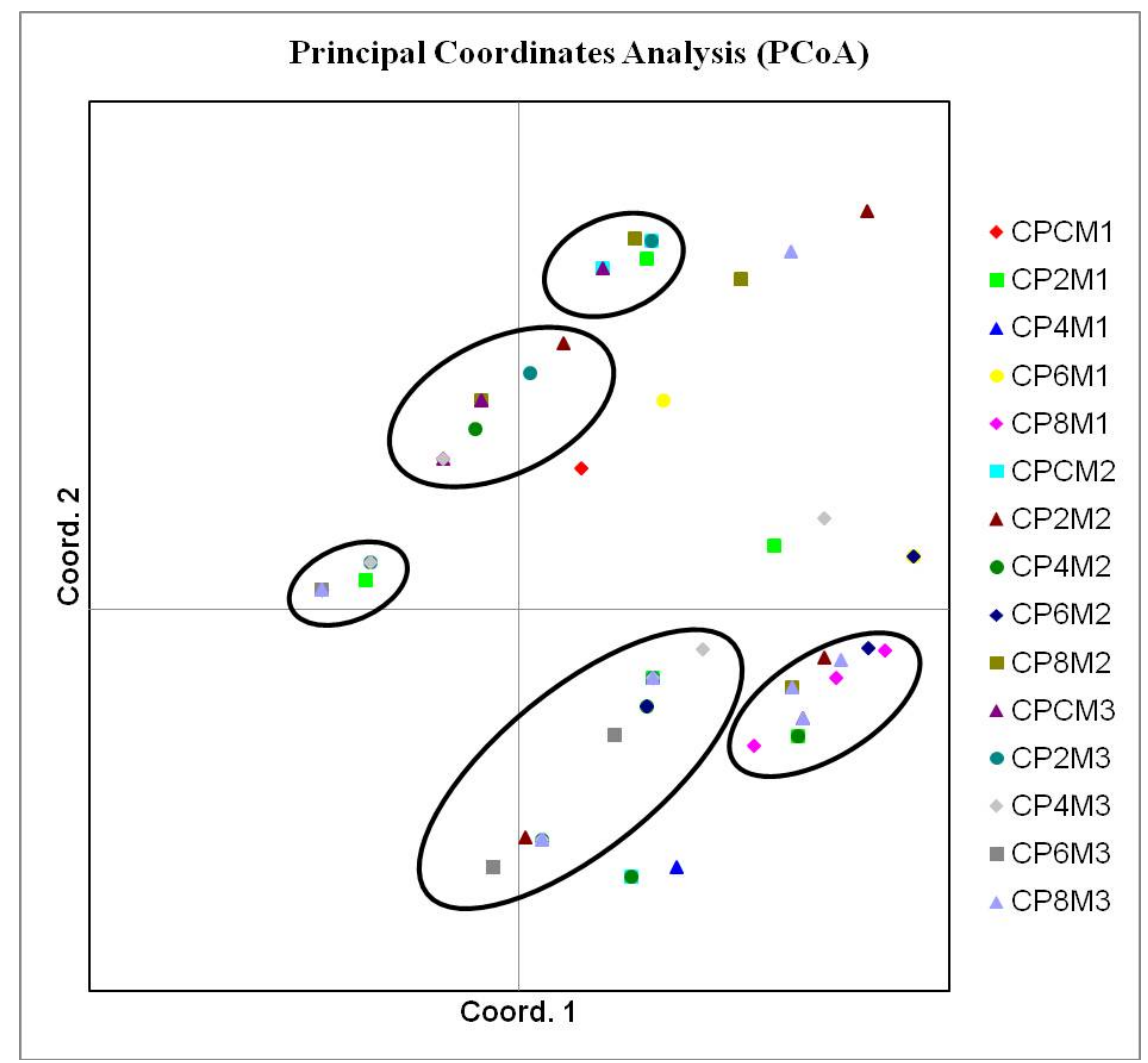

Fig. 3. $\mathrm{PCoA}$ analysis of cowpea genotypes under the treated with gamma irradiation CPC-Cowpea Control, CP2-Cowpea 200Gy, CP4-Cowpea 400 Gy, CP6-Cowpea 600 Gy, CP8-Cowpea 800 Gy

synthesis of phytohormones and nucleic acids (44). The same results were observed in enhancing plant height in black gram (45) and chickpea $(46,47)$. In $M_{2}$ and $M_{3}$ generations, the significant reduction of days for early flowering was recorded at $400 \mathrm{~Gy}$ than other doses and control. Early flowering indicates that gamma radiation-induced a short lifetime and positively impacted cowpea improvement. The present results agree with the influence of gamma irradiation in green gram (48) and pigeon pea (49).
In the present study, the increase of quantitative characters including the number of fruit cluster per plant, the number of pods per plant, pod length and hundred seed weight in second and third generations of the mutagenic population, whereas in the number of seeds per pod decreased in $\mathrm{M}_{2}$ generations but increased in $\mathrm{M}_{3}$ generation of cowpea. The present results depict the significant development of yieldrelated characters in second and third generations. These indicate that the different doses of gamma irradiation might alter the different quantitative 
characters. Similar results were found in urdbean (50) and cowpea (51). A lower dose of gamma radiation may induce yield characters by stimulating plant hormone signalling and cell components. The increasing number of seeds per pod was noted at a lower mutagen dose; similar results were observed in grass pea (52) and cowpea (53). It is noteworthy that the increasing mean values of quantitative traits are due to the incidence of polygenic mutation with cumulative effects (54). After the mutagenic treatment, the mean values changed in legumes such as urdbean (55), mungbean (56-58), lentil (59) and sesame (60).

In $\mathrm{M}_{2}$ generations, the seed yield per plant was increased at $200 \mathrm{~Gy}$, whereas in $\mathrm{M}_{3}$ generation, it was observed in both doses of 200 Gy and 400 Gy. Early flowering and high yield characters were observed in the $\mathrm{M}_{3}$ generation of Lathyrus sativus (61) under radiation treatment. A positive value in seed yield in chickpea by gamma irradiation at $600 \mathrm{~Gy}$ (47). Among the doses, $400 \mathrm{~Gy}$ induced beneficial traits especially high seed yield compared to other doses and control plants. In the present study, the lower dose of gamma irradiation-induced stimulation growth in quantitative traits due to enhanced signalling networks. Seed yield is an important trait in breeding programmes to develop better varieties. Similar findings reported that diverge genetic resources are essential for plant breeding programmes focused on developing new cultivars with desirable characters (62).

Induced mutagenesis has been effectively serviced to improve productivity and generate variability in morphological and physiological characters by inducing new plant genotypes $(63,64)$. In the present investigation, the $\mathrm{M}_{3}$ population was more superior in all traits than the $\mathrm{M}_{2}$ population due to mutation-induced at the genomic level. Gamma irradiation changes the morphological traits such as pod colour with leaflet changes, early maturity with dwarf plant and pigmented pods at 196 and 245 Gy of cowpea (22). These changes or variations can occur in plants due to irradiation treatment and are also caused by the environment.

Results herein present that the eight SCoT primers were tested for the genetic variability of three generations. Among the eight primers, seven primers were amplified and showed reproducible results. The percentage of polymorphic profiles in each primer range from 3.03-96.07\%, with an average of $67.10 \%$. The present study indicates that SCoT primers induced the appearance and disappearance of bands in three generations. Similar results findings reported that changes of DNA like single or double strands break, modified nucleotide bases, oxidized bases and bulky adducts by gamma irradiation (65). SCoT which obviously reveal the how genetic content has modified in the doses of gamma ray treated populations. Hence, gamma-ray has proved a potential mutagen for improving cowpea with desired traits based on the selection of agronomic characters. The present results are supported by earlier reports (66), that the polymorphic variations were obtained in cowpea by start codon target markers.

On the other hand, the SSR and RAPD markers showed the genetic relationship with cowpea breeding lines and wild varieties in Senegal (67). RAPD and ISSR study revealed that gamma irradiation might induce the appearance of new bands and as well as the absence in mutants than control samples of strawflower at two generations (68). The influence of gamma irradiation on corn, soybean, wheat and their result showed that the long strands of DNA broken were into small strands at a low dose (69). In contrast, short and long DNA strands are damaged at a higher dose of gamma irradiation. Similarly, the RAPD analysis showed the presence and absence of new bands in $\mathrm{M}_{1}$ and $\mathrm{M}_{2}$ generation of fenugreek tested with varied gamma irradiation doses (70).

\section{Conclusion}

A low range of gamma irradiation changed the growth and yield traits of cowpea. The $\mathrm{M}_{1}$ generation showed that the morphological and quantitative traits proportionally decreased with increasing concentrations of gamma radiation. Whereas in $\mathrm{M}_{2}$ and $\mathrm{M}_{3}$ generations showed increased quantitative traits at $200 \mathrm{~Gy}$ and $400 \mathrm{~Gy}$ and maximum variability was observed in these two doses, and it may be recommended for the beneficial traits. However, in past years, there was no much attention to improve this variety, hence, we take into consideration to induced mutation for improving the traits. The genetic study and information of this crop is poor due to we attempt to find the genetic variability by SCoT marker which one of the robust methods for assessing genetic variation. SCoT marker is a simple technique to analyse the genetic variability induced by gamma radiation. This investigation gives acceptable proof that the SCoT markers are a valuable tool to identify the genetic variation in the three generations of cowpea. The presence of a new band observed in treated samples and showed the novel mutation might occur effects of gamma irradiation. This variability may change the growth and yield traits, leads to the improvement of the crop. Hence, gamma irradiation plays a vital role in crop breeding, in which 200 Gy or 400 Gy doses of gamma rays were optimum doses to obtain the desired characters (high yield traits) for the next successive generations.

\section{Acknowledgements}

The authors thank the Department of Botany, Periyar University, Salem, Tamil Nadu, India for providing laboratory facilities for carrying out the research work.

\section{Authors' contributions}

Designing of Experiments (DAB); Fieldwork and data collection (SV and VS); Laboratory experiment, analysis of data, interpretation and statistical 
analysis (DAB and SV); Preparation of manuscript (DAB and SV).

\section{Conflict of interests}

The authors declare no conflict of interest.

\section{References}

1. Elhardallou SB, Khali II, Gobouri AA, Abdel-Hafez SH. Amino acid composition of cowpea (Vigna ungiculata (L.) Walp) flour and its protein isolates. Food Nut Sci. 2015;(6):790-97. http://dx.doi.org/10.4236/fns.2015.69082

2. Magloire N. The genetic, morphological and physiological evaluation of African cowpea genotypes. Thesis, University of Free State, 2005.

3. Ajayi AT, Adesoye AI. Cluster analysis technique for assessing variability in cowpea (Vigna unguiculata (L.) Walp) accessions from Nigeria. Rata Povrt. 2013;50(2):1-7. https://doi.org/10.5937/ratpov50-4069

4. Wongpiyasatid A, Chotechuen S, Hormchan P, Ngampongsais $\mathrm{S}$, Promcham $\mathrm{W}$. Induced mutations in mung bean breeding regional yield trail of mung bean mutant lines. Kaset J. 2000;34:443-49.

5. Dhanavel D, Pavadai P, Mullainathan L, Mohana D, Raju G, Girija M, Thilagavathi M. 2008. Effectiveness and efficiency of chemical mutagens in cowpea (Vigna unguiculata L. Walp.). Afr J Biotech. 2008;7:4116-17. ISSN 1684-5315

6. De Ronde JA, Spreeth MH. Development and evaluation of drought resistant mutant germ-plasm of Vigna unguiculata. Agric Res Council (ARC). 2007;33:381-86.

7. Gnanamurthy S, Dhanavel D, Girij M, Pavadai P, Bharathi T. Effect of chemical mutagenesis on quantitative traits of maise (Zea mays L.). Inter J Res Bot. 2012;2(4):34-36.

8. Ahloowalia BS, Maluszynki M, Nichterlein K. Global impact of mutation derived varieties. Euphytica. 2004;135:187-04. https:// doi.org/10.1023/B:EUPH.0000014914.85465.4f

9. Khan MH, Tyagi SD. Studies on effectiveness and efficiency of gamma rays, EMS and their combination in soybean (Glycine max (L.) Merrill). J Plant Breed Crop Sci. 2010;(2):55-58.

10. Thilagavathi $\mathrm{C}$, Mullainathan L. Isolation of macro mutants and mutagenic effectiveness efficiency in black gram (Vigna mungo (L.) Hepper). Global J Mol Sci. 2009;4(2):76-79.

11. Yasmin K, Arulbalachandran D, Soundarya V, Vanmathi S. Effects of gamma radiation $(\gamma)$ on biochemical and antioxidant properties in black gram (Vigna mungo L. Hepper). Inter J Radia https://doi.org/10.1080/09553002.2019.1589022

12. Yasmin $\mathrm{K}$, Arulbalachandran D, Dilipan $\mathrm{E}$, Vanmathi $\mathrm{S}$. Characterization of ${ }^{60} \mathrm{CO} \gamma$-ray induced pod trait of blackgramA promising yield mutants. Inter J Rad Biol. 2020;96(7):929-36. https://doi.org/10.1080/09553002.2020.1748738

13. Bolbhat $\mathrm{SN}$, Dhumal $\mathrm{KN}$. Induced macromutations in horsegram (Macrotyloma uniflorum (Lam.) Verdc). Legume Res. 2009;32(4):278-81.

14. Manjaya JG. Genetic improvement of soybean variety VLS-2 through induced mutations. In induced plant mutations in genomics era. Food and Agriculture Organization of the United State, 2009;106-10.

15. International atomic energy agency /mutant variety database (IAEA/MVD). 2019. https://mvd.iaea.org $6^{\text {th }}$ September, 2019.

16. Song HS, Kang SY. Application of natural variation and induced mutation in breeding and functional genomics: Papers for International Symposium; Current status and future of plant mutation breeding. Korean J Breed Sci. 2003;35(1):24-34.

17. Kharkwal MC, Pandey PN, Pawar SE. Mutation breeding for crop improvement. In: Plant breeding - Mendelian to molecular approaches. Jain HK, Kharkwal MC, (eds), Narosa Publishing House, New Delhi, India, 2004;601- 45. https://doi.org/10.1007/978-94-007-1040-5_26
18. Nagatomi S, Degi K. Mutation breeding of chrysanthemum by gamma field irradiation and in vitro culture. In: Shu QY (ed.) Induced plant mutations in the genomics era. Food and Agriculture Organization of the United Nations, Rome, 2004;258-61.

19. Mehlo L, Mbambo Z, Bado S, Lin J, Moagi S, Buthelezi S, Stoychev S, Chikwamba R. Induced protein polymorphisms and nutritional quality of gamma irradiation mutants of sorghum. Mut Res. 2013;749(1-2):66-72. https://doi.org/10.1016/j.mrfmmm.2013.05.002

20. Dhakshnamoorthy D, Selvaraj R, Chidambaram ALA. Induced mutagenesis in Jatropha curcas L. using gamma rays and detection of DNA polymorphism through RAPD marker. CR Biol.

https://doi.org/10.1016/j.crvi.2010.11.004

2011:334(1):24-30

21. Kehinder OB, Myers GO, Fawole I. Analysis of genetic linkage in the cowpea Vigna unguiculata. Pak J Trop Agric Sci. 1997;20:75-82.

22. Adekola O, Oluleye F. Induction of genetic variation in cowpea (Vigna unguiculata (L.) Walp.) by gamma irradiation. Asian J Plant Sci. 2007;6:869-73. https://doi.org/10.3923/ajps.2007.869.873

23. Silveria G, Moliterno E, Ribeiro G, Costa PMA, Woyann LG, Tessmann EW, Oliveira EAC, Cruz CD. Increasing genetic variability in black oats using gamma irradiation. Genet Mol Res. 2014;13:10332-40 https://doi.org/10.4238/2014.December.4.28

24. Collard BCY, Mackill DJ. Start codon targeted (SCoT) polymorphism: a simple, novel DNA marker technique for generating gene-targeted markers in plants. Plant Mol Biol Rep. 2009;27:86-93. https://doi.org/10.1007/s11105-008-0060-5

25. Mulpuri S, Muddanuru T, Francis G. Start codon targeted (SCOT) polymorphism in toxic and non-toxic accessions of Jatropha curcas L. and development of a co-dominant SCAR marker. Plant Sci. 2013;207:117-27. https://doi.org/10.1016/j.plantsci.2013.02.013

26. Xiong F, Zhong R, Han Z, Jiang J, He L, Zhuang W et al. Start codon targeted polymorphism for evaluation of functional genetic variation and relationships in cultivated peanut (Arachis hypogaea L.) genotypes. Mol Biol Rep. 2011;38:348794. https://doi.org/10.1007/s11033-010-0459-6

27. Nei M, Li WH. Mathematical model for studying genetic variation in terms of restriction endonucleases. Pro Nat Acad Sci. 1979;76:5269-73. https://doi.org/10.1073/pnas.76.10.5269

28. Rohlf FJ. NTSYS-pc Version. 2.02i Numerical Taxonomy and Multivariate Analysis System. Applied Biostatistics Inc., Exeter Software, Setauket, New York. 1997.

29. Page RD. TREEVIEW: an application to display phylogenetic trees on personal computers. Com Appl Biosci. 1996;12:357-58. https://doi.org/10.1093/bioinformatics/12.4.357

30. Peakall R, Smouse PE. GENALEX 6: genetic analysis in excel. Population genetic software for teaching and research. Mol Ecol. 2006;6:288-95. https://doi.org/10.1111/j.1471 8286.2005.01155.x

31. Sangsiri C, Sorajjapinum W, Srinivesc P. Gamma irradiation induced mutations in mungbean. Sci Asia. 2005;31:251-55. https://doi.org/10.2306/scienceasia1513-1874.2005.31.251

32. Gunasekaran A, Pavadai P. Effect of gamma rays on germination, morphology, yield and biochemical studies in groundnut (Arachis hypogaea L.). World Sci Newslett. 2005;23:13-23.

33. Wani A, Anis M. Gamma ray and EMS induced bold seeded high yielding mutants in chickpea (Cicer arietinum L.). Turkish J Bio. 2008;32:1-5.

34. Girija M, Gnanamurthy S, Dhanavel D. Genetic diversity analysis of cowpea mutant (Vigna unguiculata (L.) Walp.) as revealed by RAPD marker. Inter J Adv Res. 2013;1:139-47.

35. Desai AS, Rao S. Effect of gamma radiation on germination and physiological aspects of pigeon pea (Cajanus cajan L. Mill) seedlings. IMPACT: Intern J Res Appl Nat Soc Sci. 2014;(2):4752. 
36. Mensah JK, Akomeah PA. Mutagenic effect of hydroxylamine and streptomycin on the growth and seed yield of cowpea (Vigna unguiculata (L.) Walp). Legume Res. 1997;15:39-44.

37. Rizwana Banu M, Kalamani A, Ashok S, Makesh N. Effect of mutagenic treatments on quantitative characters in $\mathrm{M}_{1}$ generation of cowpea (Vigna unguiculata (L.) Walp). Adv Plant Sci. 2005;18(11):505-10.

38. Girija M, Dhanavel D. Effect of gamma rays on quantitative traits of cowpea in $\mathrm{M}_{1}$ generation. Inter $\mathrm{J}$ Res Biol Sci. 2013;3(2):84-87.

39. Thilagavathi C, Mullainathan L. Influence of physical and chemical mutagens on quantitative characters of (Vigna mungo (L.) Hepper). Inter Multidis Res J. 2011;1(1):6-8

40. Yasmin K, Arulbalachandran D. Effect of gamma rays on morphological and quantitative traits of black gram (Vigna mungo (L.) Hepper) in $\mathrm{M}_{1}$ generation. Inter J Curr Tre Res. 2016;4(2):5-12.

41. Justin Mudibu KC, Kabwe, Nkongolo, Adrien Kalonji-Mbuyi and Roger V. kizungu. Effect of gamma irradiation on morphoagronomic characteristics of soybeans (Glycine max L.). Ame Plant Sci. 2012;3:331-37. https://doi.org/10.4236/ajps.2012.33039

42. Bolbhat Sadashiv N, Bhoge Vikram D, Dhumal Konddiram N. Effect of mutagens on seed germination, plant survival and quantitative characters of horse gram (Macrotyloma uniflorum (Lam.) Verdc). Inter J Life Sci Pharma Res. 2012;2(4):129-36.

43. Khursheed S, Laskar RA, Raina A, Amin R, Khan S. Comparative analysis of cytological abnormalities induced in Vicia faba L. genotypes using physical and chemical mutagenesis. Chromosome Sci. 2015;18:3-7.

44. Pitirmovae MA. Effect of gamma rays and mutagens on barley seeds. Fiziol Res. 1979;6:127-31.

45. Arulbalachandran D, Mullainathan L, Velu S, Thilagavathi C. Genetic variability, heritability and genetic advance of quantitative traits in black gram by effects of mutation in field trail. Afr J Biotech. 2010;9(19):2731-35.

46. Rao SK. Gamma ray induced morphological and physical variations in Cicer arietinum L. Ind J Bot. 1988;11(1):29-32.

47. Khan M, Qureshi AS, Ibrahim M. Genetic variability induced by gamma irradiation and its modulation with gibberellic acid in $\mathrm{M}_{2}$ generation of chickpea (Cicer arietinum L.). Pak J Bot. 2005;7:285-92.

48. Lavanya GR, Yadav L, Suresg Babu G, Jyotipaul P. Sodium azide mutagenic effect on biological parameters and induced genetic variability in mung bean. J Food Leg. 2011;42(1):46-49.

49. Shinde MD. Assessment of variability in $\mathrm{M}_{3}$ lines of pigeonpea (Cajanus cajan (L.) Millsp.). M.Sc Thesis, Mahatma Phule Krishi Vidyapeeth, Rahuri, India. 2007.

50. Sagade SV. Genetic improvement of urdbean (Vigna mungo (L.) Hepper) through mutation breeding. Ph.D. Thesis, University of Pune, Pune (MS), India. 2008.

51. Patil MT. Genetic improvement of cowpea for agronomic traits, through mutation breeding. Ph. D. Thesis, University of Pune. 2009.

52. Waghmare VN, Mehra RB. Induced chlorophyll mutations, mutagenic effectiveness and efficiency in Lathyrus sativus $\mathrm{L}$. Indian J Genet Plant Breed. 2001;61:53-56.

53. Odeigah PGC, Osanyinpeju AO, Myers GO. Induced mutations in cowpea (Vigna unguiculata (L.) Walp.). Rev De Bio Trop. 1998;46(3):579-86. https://doi.org/10.15517/rbt.v46i3.20117

54. Singh G, Sarean PK, Saharan RP, Singh A. Induced variability in mung bean (Vigna radiata (L.) Wilczek). Indian J Genet. 2001;61:281-82.

55. Deepalakshmi AJ, Anandakumar CR. Efficiency and effectiveness of physical and chemical mutagens in urdbean (Vigna mungo (L.) Hepper). Madras Agric J. 2003;90 (7-9):48589

56. Wani MR, Khan S, Parveen K. Induced variation for quantitative traits in mungbean. Indian J Appl Pure Bio. 2005;20:55-58.
57. Tah PR. Induced macro mutation in mungbean (Vigna radiata (L.) Wilczek). Inter J Bot. 2006;2:219-28. https://doi.org/10.3923/ijb.2006.219.228

58. Arulbalachandran D, Mullainathan L. Changes on quantitative traits of black gram (Vigna mungo (L.) Hepper) induced by EMS in $\mathrm{M}_{2}$ generation. J Phytol. 2009;1(4):230-35.

59. Singh SP, Singh NK, Singh RP, Prasad JP. Mutagenic effect of gamma rays and EMSon nodulation, yield and yield traits on lentil. Indian J Pulses Res. 2006;19:53-55.

60. Ravichandran V, Jayakumar. Effects of mutagens on quantitative characters in $\mathrm{M}_{2}$ and $\mathrm{M}_{3}$ generation of sesame (Sesamum indicum L.). Intern Lett Nat Sci. 2015;(42):76-82. https://doi.org/10.18052/www.scipress.com/ILNS.42.76.

61. Girhe S, Choudhary AD. Induced morphological mutants in Lathyrus sativus. J Cytol Genet. 2002;3:1-6.

62. Govindaraj M, Vetriventhan M, Srinivasan M. Importance of genetic diversity assessment in crop plants and its recent advances: an overview of its analytical perspectives. Genet Res Inter-Hindwai Public Corpor. 2015;1-14. https://doi.org/10.1155/2015/431487.

63. Chahal GS, Gosal SS. Principles and procedures of plant breeding. Oxford: Alpha Science International Limited. 2002;399-412.

64. Khan S, Parveen K, Goyal S. Induced mutations in chickpea morphological mutants. Front Agric China. 2011;(5):35-39. https://doi.org/10.1007/s11703-011-1050-1

65. Clegg MT. Plant genetic diversity and the struggle to measure selection. I Here. 1997;88(1):1-7. https://doi.org/10.1093/oxfordjournals.jhered.a023048

66. Ezzat A, Adlyb M, El-Fikib A. Morphological, agronomical and molecular characterisation in irradiated cowpea (Vigna unguiculata (L.) Walp.) and detection by start codon target markers. J Rad Res Appl Sci. 2019;12(1):403-12. https://doi.org/10.1080/16878507.2019.1686578

67. Diouf D, Hilu KW. Microsatellites and RAPD markers to study genetic relationship among cowpea breeding lines and loca varieties in Senegal. Genet Res Crop Evol. 2005;(52):1057-67. https://doi.org/10.1007/s10722-004-6107-z

68. El-Khateeb MA, Rawia AE, Heba AM, Ashor HA, Mabrouk RMS Induction of mutation with gamma radiation in Helichrysum bracteatum L. and Identification of mutants by molecular markers. Middle East J Agric Res. 2017;6(2):282-93.

69. Yoko K, Aya M, Hiromi I, Takashi Y, Kukio S. Effect of gamma irradiation on cereal DNA investigated by pulsed field gel electrophoresis. Shok Shosha. 1996;31:8-15.

70. Hanafy RS, Akladious SA. Physiological and molecular studies on the effect of gamma radiation in fenugreek (Trigonella foenum-graecum L.) plants. J Genet Engi Biotechnol. 2018; (16):683-92. https://doi.org/10.1016/j.jgeb.2018.02.012

\section{Additional information}

Peer review information: Plant Science Today thanks Sectional Editor and the other anonymous reviewers for their contribution to the peer review of this work.

Reprints and permissions information is available at https://horizonepublishing.com/journals/index.php/PST/open_access_policy

Publisher's Note: Horizon e-Publishing Group remains neutral with regard to jurisdictional claims in published maps and institutional affiliations.

To cite this article: Vanmathi S, Arulbalachandran D, Soundarya V. Effects of gamma radiation on quantitative traits and genetic variation of three successive generations of cowpea (Vigna unguiculata (L.) Walp.). Plant Science Today. 2021;8(3):578-589

https://doi.org/10.14719/pst.2021.8.3.1054

Plant Science Today, published by Horizon e-Publishing Group, is covered by Scopus, Web of Science, BIOSIS Previews, Clarivate Analytics, etc. See https://horizonepublishing.com/journals/index.php/PST/indexing_abstracting 